\title{
Curse, Possession and Other Worlds: Magic and Witchcraft among the Bosniaks
}

\author{
Lukáš Větrovec \\ Comenius University in Bratislava
}

\begin{abstract}
This article aims to provide the readers with both the theoretical concepts necessary for studying popular magic rituals and ideas on jinn, ghosts, magic and witchcraft in Islam and on different levels of tradition in living Islam, as well as a practical excursion into the vivid contemporary everyday reality of Muslim Bosniaks, based on studying Muslim web portals and interviewing the participants. It is focused on the theoretical realm of authoritative scriptural Islam embodied by the local and global Islamic scholarly discourse in comparison with the participants' perception of their own experience. The paper attempts to find certain parallels with the situation in the rest of Europe and the Muslim world and formulate the proper conceptualisation and contextualisation of the phenomena in the light of comparative religious studies.
\end{abstract}

\section{Keywords}

Bosnia; Muslim; Islam; Magic; Sihr; Jinn; Soothsaying; Conspiracy; Possession; Curse

\section{Contact address}

Mgr. Lukáš Větrovec, Katedra porovnávacej religionistiky, Gondova 2, 81499 Bratislava, Slovakia e-mail: Alija.Harisovic@seznam.cz

\section{Introduction}

Although there have been very substantial surveys produced on the subject of sorcery and spiritual healing in Islam from the scripturalist and theoretical points of view, less is known about the actual everyday practical approach of Muslim believers in different socio-historical contexts. Several authors have compared modern conventional psychiatry with Muslim 
spiritual healing, ${ }^{1}$ introducing the concept of jinn in the Arab-Islamic tradition, ${ }^{2}$ discussing possession, ${ }^{3}$ or speaking about jinn possession from a Qur'anic perspective. Field research has primarily been conducted by psychologists, psychiatrists or experts in mental health, who focus either on very concrete issues, such as the culturally conditioned interpretation of postnatal illness or a subjective interpretation of psychological "well-being" among certain groups, e.g. young female Somali refugees and asylum seekers or trying to provide an overall discussion of local Muslim understanding of mental disease and its traditional treatment. ${ }^{4}$ This could or could not be primarily connected with magic and witchcraft experiences or deal with magic and witchcraft just partially when it has some connection with healing. Some studies have also been genderized. ${ }^{5}$ None of these studies provide us with deep insight into the actual beliefs and practices of the people or enables a suitable synchronical or diachronical comparison with anticipated concepts known from religious texts or similar cases in other historical periods and geographical areas inside or outside the domain of majority Muslim societies. And last but not least, none of these studies concentrate on the situation within traditional European Muslim communities on the eastern part of the continent. These subjects tend to be quite neglected by western Islamological discourse in general, due to a lack of concern (western studies classically deal with immigrants or operate in formal colonies in the Middle East and North Africa region). This is also due to difficulties in understanding the specific conditions and realities of those Europeans of Muslim belief, given by their long history of being minorities under secular regimes led by others and/or their countries' experiences with totalitarian regimes of Communist parties either independent or under Soviet influence. Pauly, for instance, discussing Muslims in Europe and their demographics, mentions Bosnia and the Bosnians (in reference to Islam proper to speak about Bosniaks - formal "Bosnian Muslims") in the case of their diaspora in Germany, ${ }^{6}$ war refugees in the $1990 s^{7}$ and German anti-immigrant sentiment. ${ }^{8}$ There is no mention of Bosnians as autochthonous Europeans, but this is not Pauly's fault since he simply reflects a common trend among Western researchers.

The richest in content is Norris's introduction to the Islamic culture of the Balkans which is, however, concerned more with cultural heritage, Sufism and many different

\footnotetext{
${ }^{1}$ E.g. Simon Dein and Abdul Samad Illaiee, "Jinn and mental health: looking at jinn possession in modern psychiatric practice," The Psychiatrist 37 (2013): 290-293.

${ }^{2}$ E.g. Amira El-Zein, Islam, Arabs and the Intelligent World of the Jinn. (Syracuse: Syracuse University Press, 2009); Christian Suhr, "The failed image and the possessed: examples of invisibility in visual anthropology and Islam," Journal of the Royal Anthropological Institute. 2015. http://onlinelibrary.wiley.com/ doi/10.1111/1467-9655.12168/full.

${ }^{3}$ E.g. Najat Khalifa and Tim Hardie, "Possession and jinn” JRSM, 98 (August 2005): 351-353.

${ }^{4}$ Yaseen Ally and Sumayya Laher, "South African Muslim Faith Healers Perceptions of Mental Illness: Understanding, Aetiology and Treatment," Journal of Religion and Health no. 47 (2008): 45-56.

${ }^{5}$ E.g. Gerda Sengers, Women and Demons: Cult Healing in Islamic Egypt (Leiden: Brill, 2003).

${ }^{6}$ Robert J. Pauly Jr., Islam in Europe. Integration or marginalization? (Aldershot, Hants: Ashgate, 2004), 3; 69-70; and 82.

${ }^{7}$ Pauly, Islam in Europe, 66; 71; 87; and 98.

${ }^{8}$ Pauly, Islam in Europe, 83.
} 
Balkan contexts and does not overcome the classic orientalist fascination with the texts and writings forming the culture. Although innovative and erudite, it does not say hardly anything about everyday Islamic practices in Bosnia, including magic and related issues. ${ }^{9}$

According to Pew Research Center's poll entitled The World's Muslims: Unity and Diversity, 36\% of polled Bosniaks who consider themselves Muslims, do believe in jinn, which is higher than the European average (30\%), but only $21 \%$ believe in sorcery (31\% is the European average) and 37\% in the evil eye, the least from all European Muslim nations surveyed. Bosniaks also seem to be the least likely to use traditional faith healers $(16 \%, 23 \%$ is the European average) or to wear talismans for protection against evil (13\%, $24 \%$ is the average), but $77 \%$ of them display Qur'anic verses on the walls of their homes, which is the highest number encountered in Europe. The survey also demonstrates that the people in Bosnia are the most likely $(5 \%)$ to be witnesses of exorcism (evil spirits/jinns driven out of a person) from all of the Muslim Europeans polled, although the number is quite small in worldwide comparison. ${ }^{10}$ A quite significant number of Bosnian Muslims, even in worldwide comparison (12\%) support offerings and appeals given to jinn, which is the basic principle of sorcery in Islam.

Our research is based on the premise of Thomas's theorem:"If people define situations as real, they are real in their consequences." ${ }^{11}$

The Bosnian case is also suitable to demonstrate various approaches in anthropology towards the phenomena. This region has been continually inhabited since the Ice Age, which can be documented by genetic and archaeological proof. Three main ethno-religious communities live there at present, speaking very similar languages and sharing basically the same cultural milieu. The relations between them oscillate from peaceful coexistence to very substantive enmity with tendencies to annihilate each other. This stresses the need for and identity search.

On the Bosnian experience, we can further put to test:

Functional hypothesis - survival of that practice or belief serving the identity or explanatory function the best.

Interpretation hypothesis - preferred is that belief or practice which seems to fulfill the demands of people who meet with such phenomena.

Confirmation hypothesis - preferred is that belief or practice that is congruent with beliefs or practices of the participants' group.

Cultural antagonism hypothesis - preferred is that belief or practice which enables fighting the beliefs and practices of the competing group the best.

Last but not least, the actual situation of sorcery in Bosnia seems to also be one of several issues constructing the idea of "mass/or pop-" Islam and helps to overcome an outdated dichotomy between scholarly and rural/folk Islam.

\footnotetext{
${ }^{9}$ Harry Thirlwall Norris, Islam in the Balkans. London: Hurst\&Co, 1993.

${ }^{10}$ Louis Lugo, The World's Muslims: Unity and Diversity, (Washington: Pew Forum, 2012), 67-82.

${ }^{11}$ Wiliam Isaac Thomas and Dorothy Swaine Thomas, The child in America: Behavior problems and programs (New York: Knopf, 1928), 571-572.
} 


\section{Methodology of the Practical Part}

The field research in Bosnia (August 2017 and January 2018) and Bosnian cyber-space (September 2017) brought interesting data on sorcery and magic practices which can be approached with several methodological tools.

There is the method of "thick description" by C. Geertz, concisely describing what is seen and giving the sense to the seen, separating the meaningful from the meaningless elements. ${ }^{12}$ Geertz says:

"Doing ethnography is like trying to read (in the sense of 'construct a reading of') a manuscript-foreign, faded, full of ellipses, incoherencies, suspicious emendations, and tendentious commentaries, but written not in conventionalized graphs of sound but in transient examples of shaped behavior." 13

The concept of "religious worlds" according to W. E. Paden, where one and the same phenomenon could have more possible explanations in the eyes of participants, when each of them sees the same thing differently and in accordance to his world and his perception of reality, where the observed thing makes sense to him in the given world-view.

During the field research, several cases of cursed places (two - the Viječnica case and Todorovo case) and media affairs (the cases of Turabi and Hosein) were discovered connected to magic and sorcery and mentioned and discussed in the public media. During the cyber-space research these cases were followed carefully and as much material as possible was collected for further discourse analysis of the contents especially related to their interpretations and the reactions of the different participants.

In the cyber-space analysis, the author of this article used two extremely popular websites relevant in the Bosnian context:

1. - Svet tajni (www.svettajni.com), a Serbian web-portal with a classic European mysterious agenda typical for the entire wider region of post-communist countries: paranormal activity, UFOs, conspiracy theories, alternative medicine. This web also mentioned the cursed places of Bosnia and one case of Balkan Muslim magic where the victim was an orthodox Christian women from Serbia.

2. $-N-U M$ (www.n-um.com), a Bosnian Islamic web-portal functioning as a switchboard from several other websites of official Islamic authorities in Bosnia (IZ - Islamska Zajednica or Islamic Community) ${ }^{14}$, pro-salafi NGOs led mostly by graduates from Medina, Riyad and other Saudi and Gulf learning centres with no affiliation to IZ and also the personal web presentations of rakis - spiritual healers. Eye-witness reports about concrete encounters with magic were collected here.

${ }^{12}$ Clifford Geertz, The iterpretation of cultures (New York: Basic Books, 1973), 5-6.

${ }^{13}$ Geertz, The interpretation, 10.

${ }^{14}$ Official institution and structure governing the religious life of Bosnian Muslims in Bosnia and the diaspora, ascribes itself to the madhhab of Abu Hanifa, the aqida of imam al-Maturidi, Ottoman and Sufi heritage and secular experience, seen by its representatives as the "Islamic tradition of Bosniaks." 
For an analysis of collected data from these witness reports, the method of descriptive coding (or topic coding) was used. ${ }^{15}$

Here is the list of questions for the collected witness stories:

1. Victim - age, religion, occupation, prerequisite knowledge, ...

2. Symptoms, how long, periodicity, preceding medical anamnesis ...

3. Type of attack - magical, possession, evil eye...

4. Cause of attack, kind of sorcery used, possible explanation ...

5. Type of healing, effectiveness, healer, communication with other worlds ...

6. Interpretations by victim, by environment (family, peers, colleagues), by healer, medical experts ...

7. (Optional) Notes - is there any striking consistence/inconsistence with expectancies of "Islamicity"/"unIslamicity" in the participants' world-view?

These questions provided us with the base for our coding of topics and subtopics and their further quantification.

The semi-structured interview with a raki - spiritual healer was related to these discussion topics:

1. What is your religious knowledge background, how did you become a raki.

2. What are the healing methods you use in your practice.

3. What are your opinions of folk healing.

4. What is your opinion of conventional medicine.

5. How would you summarize your experiences with jinn.

6. Do you have some details about the connection between jinn and the diseases you found interesting?

Whenever the author of this article knows the names of the participants of the encounters, he only provides the initials and not all the names, due to ethical reasons and privacy policy.

\section{Theoretical Background for the Study of Magic Phenomena in Bosnia}

\section{Historical layers of Bosnian folklore}

Beliefs in other worlds and forces affecting people's lives is shared among different cultures both in the synchronical and diachronical perspective. The Bosnian case is a result of a layering of tradition from different time periods and multiple geographical and cultural zones.

${ }^{15}$ See further in Johnny Saldaňa, The coding manual for qualitative researchers (Los Angeles: SAGE, 2009), 88. 
The reality observed is the result of a layering of previous beliefs which mix and interact with the new-coming one, prove to be useful and relevant, change their earlier function or gain new functions or are replaced by new cultural elements. The idea of atavism (E.B. Taylor's "survivals"), pertaining to seemingly irrational beliefs and customs as vestiges of earlier religious practices enables us to track the origin of the concerned belief, custom or practice. This idea does not mean in any way, however, that the practices observed now are basically or nearly the same ones as in some historical stage of culture. They are indivisible, organic parts of the actual cultural landscape with an irreplaceable function in society's world-view.

While studying witchcraft phenomena in Bosnia and the wider Balkans, these historical layers can be detected:

\section{A. Proto-Balkan beliefs}

Pre-Slavic Ilyro-Roman or even an older origin is assumed for the cultural elements listed below:

1. Sacrifices while building new structures, the ritual need to spill blood (bos. pustiti $k r v)$ of the sacrificed animal or human being, originally to get the protective spirit to defend the new building. In modern days the residues of this practice can be seen in local legends of cursed places and haunted houses claiming lives.

2. The dead predecessors cult and grave worshipping. Dead people are viewed as a source of strength, wisdom and spiritual abilities for the living. In one of our stories, the magician sleeps in his father's grave to get spiritual strength.

3. The cult of the snake: Štulanović mentions from his friend's (a doctor from Bihać) grandfather - a famous hodža who also knew occult sciences and the arts of zapis, how to call, gather and manipulate snakes of different kinds, shapes and colours, using rukja and a stick made of a fallen branch. ${ }^{16}$

4. The cult of fire: Hangi reports fire usage in the processes of healing and destruction of magic attacks and its means. ${ }^{17}$ There is a strong connection between the fire cult and the iron cult with a strong emphasis on the figure of the smith.

5. The tree beliefs regarding magical procedures (a positive yew-tree and a negative walnut tree, the habit to plant a lime tree nearby mosque) are either of Slavic origin or even older.

\section{B. Old Slavic beliefs}

The rituals with magic background or outreach practiced by ordinary peasants (agricultural superstitions) or marital magic practiced by young girls which are certainly of Slavic origin with possible older admixtures. A very Slavic phenomenon is also the concept of the curse (bos. Kletva). A belief about a good snake protecting the house (bos. kucna zmija) can also be found in other contexts (even in Islamic) but the Slavic origin poses the most plausible

\footnotetext{
${ }^{16}$ Muharem Štulanović, Zapisi u BiH (Bihać: Islamski Pedagoški Fakultet, 2016), 20-21.

${ }^{17}$ Antun Hangi, Život i običaji Muslimana (Sarajevo: Svjetlost, 1990), 85.
} 
explanation. The hunter superstition of a hare paw - right for good and left for bad luck also belongs to this layer. Many folktale characters such as fairies or revenants are of Slavic origin. All of these beliefs and folk practices can be documented from the ethnography of other Slavic nations across Europe. According to Duranović, these elements are most numerous and include superstitions of life cycle, agriculture and the animal or plant world. ${ }^{18}$

\section{Early Christian beliefs.}

The belief in drekavci - ghostly malevolent beings originating from the souls of unbaptized babies, commonly found in South Slavic folklore was Islamized amongst Bosniaks into a belief of the same beings originating from babies who died unnamed, uncircumcised or without a proper Islamic procedure. Bosniaks sometimes pray for rain in old cemeteries or celebrate Jurjevo or Đurdev dan celebrations with Christians celebrating the Feast of St. George. In sorcery practices, several reports mention even reading the Qur'an backwards. Some magicians use salt "consecrated" with an Islamicized enchantment in healing rituals. ${ }^{19}$

D. Oriental beliefs.

All beliefs of Oriental origin, mainly the Islamic beliefs, belong to this category. From them, the concepts of jinn, sorcery, communication with the unseen and beliefs about Arabic letters, celestial bodies and days of the week or months of the year are relevant. The Oriental elements in Bosniak beliefs and practices are mostly, but not exclusively, Islamic, since the form of Islam spread here by the Ottoman Empire was already influenced by many Arab, Turanic and Iranic influences after eight centuries and a 6,000 km long journey from Mecca and Medina to Bosnia. A typical example is the cult of sufi saints (bos. evlije) and their shrines (bos. turbe). ${ }^{20}$

E. Modern urban legends and Western pop-culture.

The newest layer is represented by popular practices streaming out of new-age fashion, spiritual energies inspired by Eastern beliefs, theosophic notions of old unknown civilizations and their ancient wisdom or folklore revivalism tendencies.

Layering certain folk practices is not always clear since there exist more opinions and views especially in the oldest layers. For instance, Hadžijahić speaks about a continuity in Ilyrian, Roman and Slavic practices continuing even to Christian times in certain beliefs and practices of the Bogumil Church. ${ }^{21}$

According to Yoder, national beliefs are residues of older religious beliefs still prevalent among people in rural or peripheral areas conflicting with official or proclaimed religious

\footnotetext{
${ }^{18}$ Elvir Duranović, "Narodna religijaDuranović, "Narodna religija, narodni Islam u Bosni i Hercegovini bosanski Islam i Islamska tradicija Bošnjaka - diferencirajući faktori" Glasnik IZ 11-12(n.d.), 1083.

${ }^{19}$ Tihomir Đorđević, Naš narodni život. (Beograd: Prosveta, 1984), 2:262-267.

${ }^{20}$ Duranović, "Narodna religija," 1084.

${ }^{21}$ Quoted via Duranović, "Narodna religija,” 1082-1083.
} 
affiliations and syncretic penetration or a blending of older and newer practices. ${ }^{22}$ In the Christian context, folk beliefs are traditionally connected to pagan times, but are currently viewed as all the beliefs of local Christian communities with no direct relation to the Church catechism. ${ }^{23}$ Although the author of this article does not see a problem in broadening this perspective to even a Islamic context, he strongly disagrees with the idea of syncretism as an artificial dichotomy. From the perspective of the participants, the methods of popular usage against magic and harm caused by unseen attackers are seen as Islamic because they are part of the Muslim community heritage inherited from forefathers. Their origin is not taken into consideration and they are not approached as Ilyrian, Slavic or early Christian in their origin. The cultural heritage is passed down to the further generations as a whole, as a multi-functional complex of beliefs and practices. This is also the case with Bosnian Islamic tradition, as it is used as terminus technicus by Bosnian Islamic scholars and intellectuals, such as Fikret Karčić. The Islamic tradition of the Bosniaks includes in his view Sunnism, Hanafism, Maturidism, related Sufi Tariqahs, the Ottoman cultural heritage, Islamicized elements of pre-Islamic Bosnian culture, the tradition of modern Islamic reform, institutional practice under the Islamic Community in Bosnia (bos. Islamska zajednica u Bosni i Hercegovini) and the practicing of Islam under the realm of the secular state. ${ }^{24}$

\section{A typology of specific contents}

Antun Hangi, one of the first ethnologists writing on Bosniaks at the beginning of the twentieth century mentions beliefs in sihir, mora and vjestica (witch). ${ }^{25}$

Sibir or sibr is a pan-Islamic kind of magic, can be secretly put in water or inside a house of the victim or picked up on the road. ${ }^{26} \mathrm{Sihr}$ can be made to harm (cause illness, madness, death) a specific person, to destroy a relationship, gain love or bring material harm.

Mora is attack of an unseen force causing choking and panic in persons falling asleep or waking up from sleep.

Urok or the evil eye, is the simplest kind of magic from an envious person who stares at another person or thing which he envies. Urok can be involuntary when someone stares at something he/she likes or admires and forgets to say "ma ša Allah" - "as Allah wants." Amall children are believed to be most vulnerable so sometimes a red string is knotted for them. ${ }^{27}$

Ograma or the touch of a jinn. In this case, a jinn just harms someone but does not enter him. Traditionally it was associated with a walnut tree. ${ }^{28}$

\footnotetext{
${ }^{22}$ Don Yoder. "Toward a Definition of Folk Religion," Symposium on Folk Religion 33: 1(January 1974), 14.

${ }^{23}$ Yoder. "Towards a definition," $12-13$.

${ }^{24}$ Duranović, "Narodna religija,", 1086.

${ }^{25}$ Hangi, Život i običaji, 111-112.

${ }^{26}$ Hangi, Život i običaji, 107.

${ }^{27}$ Mevlida Serdarević and Ajnija Omanić, Bošnjačka kultura ponašanja (Sarajevo: Art 7, 2009), 320.

${ }^{28}$ Hangi, Život i običaji, 107.
} 
Possession (bos. opsjednutost): There is a jinn living inside the patient's body, for whatever reason - an alliance with a sorcerer, a struggle to escape from danger, vengeance or, what is the worst case, a jinn's love for the person. Affected people change their attitude and behaviour, speak in other voices or sometimes in unknown languages, behave as if in a trance, sometimes bleed from body orifices ${ }^{29}$

Zapis: Magical writing of an Oriental origin, one of the most typical means of magic. The first book written on this topic was Šams al-macārif al-kubrā of Ahmad ibn 'Alī al-Būnī (North African Sufi author, died in 1225), who used already existing Oriental concepts, operating with geometrical shapes in relation to astronomical bodies, angels and days of the week. It has four volumes with cca 600 pages for each of them. Similar shaped talismans were used in Europe by Agricola. ${ }^{30}$ In Bosnia this knowledge was widespread before World War II, as documented by Garčević. ${ }^{31}$ He studied these sciences under Bosnian and Turkish shaykhs and also used al-Būnī's text as a source in compiling his own book alongside other sources in Arabic, Turkish and Bosnian, dating from the fourteenth to the nineteenth centuries. ${ }^{32}$ Zapis often uses some characters in cyphered scripts. Garčić mentioned pictures of 17 different scripts. ${ }^{33}$ This can be done with Qur'anic verse or other Islamically legislated methods or by using other, more heterodox, formulas. Hamajlija is the specific kind of zapis hanging on a person's body. ${ }^{34}$ Sometimes these amulets were sewn inside clothes or caps, or whole shirts served as one big hamajlija. ${ }^{35} \mathrm{~A}$ special kind of zapis can also be a talisman - which gives its owner some special powers.

Daira is an Arabic term for a circle, in Bosnia some hodžas and sihirbazs tried to mimic the communication between the Prophet Muhammad and jinns when he invited them to Islam. ${ }^{36}$ The circle was drawn on earth, water, mirror, fingernail or palm, sometime a blue- or green-eyed child was used as a medium. This enabled them to ask them for roots of illnesses or for some hidden truths. ${ }^{37}$ This was considered very dangerous and risky. ${ }^{38}$

\section{Active participants}

From the perspective of the active originators or generators of magic practices and rituals in a Bosnian context, they can be divided into two distinct categories:

\footnotetext{
29 Štulanović, Zapisi u BiH, 29.

30 Štulanović, Zapisi u BiH, 40-41.

${ }^{31}$ Garčević, Muhamed. Zapisi i hamajlije (Sarajevo: Hrvatska narodna tiskara (podružnica), 1942), I.

32 Štulanović, Zapisi u BiH, 45-47.

33 Štulanović, Zapisi u BiH, 51-59.

${ }^{34}$ Garčević, Zapisi i hamajlije, 8.

${ }^{35}$ See picture in Štulanović, Zapisi u BiH, 78.

${ }^{36}$ See Qur'an, 72:1-28 and the reason for its revelation.

${ }^{37}$ Garčević, Zapisi i hamajlije, 24-25.

${ }^{38}$ Garčević, Zapisi i hamajlije, str. 27.
} 
A. Religious and magic specialists

Hodža or dervish as the imminent representatives of Islamic scholarship served for spiritual treatment of human illnesses from despair to unhappy love to severe infections. The spiritual methods were also used to treat farm animals such as horses or cattle. ${ }^{39}$ Sometimes Muslims visited Christian priests and asked them to do zapis for them, or the Christians visited hodža. ${ }^{40}$

The non-religious specialists in folk healing and magic methods were men and women called vračar or vračara resp. stravarka. One of the last of them is stravarka Fatka Hasanović of Banovići (North-East Bosnia). ${ }^{41}$ Sometimes, the smith or his wife combined in rural areas the role of vračar or vračaralstravarka.

The main problems people asked their help for included marital dissolution, delusional thoughts, illnesses of every kind, love, madness, bleeding, idleness and procrastinated weddings. The methods they used were almost always contagious.

\section{B. Commoners}

There exist several methods or folk practices which can even be used by ordinary people. The most famous of these are either:

Folk soothsaying called falanje (from Persian fal-presage) or gatanje (fortune-telling). As in other countries with a culture of drinking coffee, the coffee grounds were typically used. Typically Bosnian is the use of bean grains - favomancy (bos. falanje u grah). It is sometimes viewed as reminiscent of ancient practices of osteomancy. The fortune-teller holds 41 grains in his right hand near his mouth, he can recite over them either some Qur'anic verse or rukja or whatever and blow on them. He then throws them down, adding the last grain and concentrating on his aim. Then the position of grains, their grouping and number are read.

The second is bajanje (enchantment) using folk incantatory formulas called basme uttered by common people in specific situations on the occasion of folk rituals during certain holidays or important moments in time. Some basme were in the form of short poems or songs while others used incomprehensible words mimicking the Arabic wording of Qur'anic texts or widely used Muslim supplications.

Folk magic used by commoners in most cases used not to be contagious. While gatanje and falanje have a strong connection with fortune telling, bajanje is related to issues of love, protection against evil, agriculture and healing.

\footnotetext{
${ }^{39}$ Hangi, Život i običaji, 86.

${ }^{40}$ Hangi, Život i običaji, 87.

${ }^{41}$ See more in this video where she warns against leaving washed laundry on the clothes line until the next day. <https://www.youtube.com/watch?v=43Y0RIEK8WE> [17.IX.2017]
} 


\section{Magic and sorcery in contemporary Islamic scholarly debates in Bosnia}

The issue of spiritual healing, jinn, causing problems and sorcery in Bosnia, has been addressed since the 1990s due to a wider opening of the society towards religiosity, occultism, magic and esoterism and - in particular - with the renaissance of Islam in the country during and after the last Bosnian war (1992-1995). The most appropriate, according to scholarly teaching of Islam, is the method of Qur'anic healing (in Bosnia called rukja). Štulanović, one of the main Bosnian authors writing about conflicts between scholarly and folk practices and the major senior expert in Qur'anic healing, states that this proper Islamic method during the last regime was widely forgotten. ${ }^{42}$ In contrast, the method of healing by means of zapis or folk methods of healing and soothsaying, is usually by means of coffee spoons. ${ }^{43}$ The renaissance of Islamic spiritual healing began in the Austrian Bosniak diaspora because of contacts with rakis from Cairo's al-Azhar. In Bosnia they began to make group séances of rukja, as in Vrhpolje near Sanski Most. Štulanović, as a leading Bosnian expert in this field, experienced, as he said, misunderstandings from the official Islamic authorities in the country. ${ }^{44}$ Representatives of IZ tended to be quite reluctant to address these issues but with the further influx of different magic and occult practices they were forced to. Štulanović asked IZ for institutionalization of this field of science but his appeal was not successful. ${ }^{45}$

\section{Case Studies}

\section{Cursed places}

\section{Sarajevo's Old City Hall}

The celebrated, newly reconstructed and reopened, Sarajevo Old City Hall called Viječnica, is according to Bosnian newspapers Slobodna Bosna's article from October 3, 2012, said to be the most famous cursed place in Bosnia, ${ }^{46}$ connected with a series of violent events and disasters since it was built in 1885. During its construction, a bucket full of concrete fell and killed one of the workers. Franz Ferdinand d'Este and his wife Sofia visited Viječnica soon before they were assassinated in 1914. In 1951, the formal City Hall become the Bosnian National Library but in that same year A. B., a local 30-year old servicewoman attempted suicide here. In 1964, the director V. K. hung himself in Viječnica, followed soon after by a 37 -year old typist K. K. In the mid 1970s, a local worker B. Č. was hurrying home, fell down the stairs, injured his head and died, but the media referred to it as

\footnotetext{
42 Štulanović, Zapisi u BiH, 40.

43 Štulanović, Zapisi u BiH, 14-16.

44 Štulanović, Zapisi u BiH, 30-31.

45 Štulanović, Zapisi u BiH, 131-136

46 See further at "Zona sumraka: Istina, mitovi i legende o prokletstvu Viječnice, “ Slobodna Bosna, Accessed at September 162017 <https://www.slobodna-bosna.ba/vijest/2638/zona_sumraka_istina_mitovi_i_ legende_o_prokletstvu_vijecnice.html $>$. This is the oldest article on this issue and the richest in content.
} 
a heart attack. In 1983, a doorman I. P. shot his best friend with nine bullets for reasons still unknown. In 2000, the architect T. H. died under a collapsed 5 ton staircase during reconstruction work. According to several witness reports, Viječnica is haunted, there can be crying, shouting and strange sounds heard and there are mysterious shadows seen above the exhibits. There are no written references to the curse of Viječnica, everything being based on oral stories. Some say the problem is that there was no sacrifice before the construction of this building. Others believe that the land where the building stands belonged to a rich burgher, pasha Mustafa Babić whose garden is just behind the Miljacka river as well as the mosque he built, nowadays called Hadžijska, because the pilgrims used to meet there before they left for Mecca. Pasha Mustafa revolted before the end of Ottoman rule against the sultan, escaped execution in 1851 and died in exile in Bursa, Turkey. His co-fighters were hanged, however, in a small square in front of his house, where Viječnica now stands. There were also other executions carried out here.

According to a third version, three young architects - Karel Pařík, Alexandr Vítek ${ }^{47}$ and Ćiril Iveković quarreled about how to represent the European spirit in the new City Hall building. Vítek's project won. It was a pseudo-moorish style inspired by similar buildings in Alexandria, Cairo and Granada, but Pař́k who was known as an egoist plotter, was angry. They gave him the project of the city prison as compensation. Meanwhile Vítek traveled to Cairo for work and someone began to work on Viječnica without his permission and in a way he found unsuitable. The New City Hall faced Miljacka and not the old trade avenue Baščršija and there was not sufficient light inside the building as Vítek planned. He was devastated and hospitalized. Iveković continued with the construction work and was asked by the mentally ill Vítek to bury him inside the City Hall in special chamber he designed for himself. Vítek had an attack of seizures and spoke in an incomprehensible language supposedly cursing the building. He committed suicide soon after. After attackers burned Viječnica down in 1992, they found behind the thick wall a chamber unknown before, large enough to be a burial chamber.

According to the last theory, this curse is in fact a punishment for disrespect for the old Ottoman construction principles ruled by the Islamic law of right to see and the right not to be seen. Every new building should be constructed in the way so as not to obstruct the view of the people and also not to provide a possibility from the outsiders to see what is hidden inside the privacy of houses. It is possible to look into the private gardens behind Miljacka river from Viječnica, which contradicts the Islamic prohibition to observe someone other's privacy.

\section{The "Ghost House" of Todorovo}

There is a house said to be haunted in the far north-west frontier in the municipality of Todorovo near the border town of Velika Kladuša. The case gained wider international

${ }^{47}$ Lived 1853-1894. Also mentioned in a German transliteration as Alexander Wittek. 
publicity in several media, newspapers, radios and television, including local VK Portal's article from August 1, 2012.48

The house is situated on a crossroads and is dilapidating slowly. Local citizens consider the place cursed and avoid it. According to local legend, local religious representatives planned to build a school there in the mid nineteenth century. There came there to check the land and perform all the necessary measurements for two days and had to spend the night in tents. At night, however, they were expelled by some sort of unexplained force and the school was never built. After a certain time, the Bašić family bought the land. The first house was built before World War II by Husejn Bašić. After it burnt down, Hasan, Husejn's brother, tried to build another house in the same place, but Husejn tried to convince him not to do it since the place was cursed. According to several local sources, Hasan died shortly after he finished the house. During the last war in 1the 990s, there was a front-line between the fifth army unit of the Bosnian army and the paramilitary units of $\mathrm{APZB}^{49}$ fighting the Sarajevo-based government. The soldiers entered the house, devastated all the furniture and inner equipment and broke all the windows. The house now is actually the third one at the same place, since cca 25 years ago. No one settled in the place after the war because of the belief this place was cursed.

Witnesses report hearing punches, blows, unpleasant sounds and crying. Mobile phones lose their signal, electronic equipment breaks down, people feel physically uncomfortable, experiencing fatigue, headaches, nausea, wanting to vomit, sweating and goose bumps.

According to some reports from eye-witnesses, there used to be a cemetery there. Other speak about a World War II massacre and a mass grave down in the basement of this building. According to the third group, there was a room where some of the last war parties tortured and executed the captives of the other faction.

\section{Media affairs}

\section{The Mekki Turabi case}

Mekki Turabi, self-proclaimed Moroccan spiritual healer, condemned as an impostor and sorcerer by leading Islamic scholars in the world (such as Yusuf al-Qardawi), visited Sarajevo in autumn 2010. He is famous all over the globe for his healing through touch, enchantments, amulets and "hallowed" water. During his séances, Mekki falls into an altered mind-state and speaks incomprehensible languages. Fetva-i emin ${ }^{50}$ of Bosnia, Dr. Enes Ljevaković condemned his practices as unIslamic and expressed fears from his

\footnotetext{
${ }^{48}$ See "Svjedočanstva mještana o "Kući duhova" u Todorovu,", VK Portal, Accessed at September 162017. $<$ http://www.vkportal.ba/svjedocanstva-mjestana-o-kuci-duhova-u-todorovu-foto/> All other articles and reports are taken from this first source, including the Serbian mystic portal Svet tajni with his article "Ukleta mjesta u BiH: Duhovi, ubistva i čudne pojave," Accessed at September 16 2017. <http://www.svettajni.com/ paranormalne/ukleta-mesta-u-bih-duhovi-ubistva-i-cudne-pojave/>. See also a video here: <https://www. youtube.com/watch?v=CxWrS8MmUZo> Accessed September 142017.

${ }_{49}$ Autonomous region of Western Bosnia (Autonomna pokrajina Zapadna Bosna), war entity led by the Bosniak politician and warlord Fikret Abdić.

${ }^{50}$ Grand mufti, highest IZ representative for fetva issuing.
} 
"quackery." ${ }_{1}$ The sorcerer returned the following year. IZ issued a condemning statement forbidding Muslims from attending his shows in Zetra stadium. There were thousands of people, however, waiting for his program. ${ }^{52}$ Turabi's case initiated an exceptional session of the Council for Fatwas (Vijeće za fetve) of IZ Headquarters on 15 June 2011. The Council agreed on a response where Dr. Enes Ljevaković stated:

"Based on the Glorious Qur'an and Sunnah of Allah's Messenger, peace be upon him, after consideration of the statements and healing methods of the healer Mekki Turabi himself, the Council for Fatwas concludes, that his performance is unacceptable. Such kind of quackery is forbidden (haram) by Sharia, also the attending of his healing séances or its support by means of cooperation, help with organizing, propagation or advertisement is in the terms of Sharia prohibited as well as other such activities which include deceiving superstitious people and manipulating their wishes and needs." 53

Based on the aforementioned fatwa, the Council warned the believers against such séances expressing their deep concern and stating that such programs harmed the picture of the country abroad. The Council formulated a demand:

"Based on what was mentioned above, the Council for Fatwas of IZ in Bosnia and Herzegovina asks state authorities, the medical and scientific expert public to stop the frauds and shame cast on our society by Mekki Turabi and his séances." ${ }^{4}$

The Council also required this fatwa to be read in all mosques the following Friday during sermons. The Council's statement was widely respected and IZ was also consensually supported by the local pro-salafi NGOs, otherwise strong critics of its inner policy. ${ }^{55}$

\section{The Imran Hosein case and "The Arrivals" series}

The author of this article received from his friend in Sarajevo in 2008 a CD with the conspiracy documentary series "The Arrivals." The 50-episode (7-8 hours long in total) series is of foreign origin (probably Lebanese Shiite in cooperation with Western converts) with Bosnian subtitles and deals with Islamic prophecies of Doomsday, conspiracies, NWO, jinns, Satanism and mysterious signs appearing in Western pop-culture. The series was removed from YouTube because of copyright infringement, but is available on-line in other places. ${ }^{56}$ The main argument of the series is briefly that western mass culture led by the USA is Satanic and functions, led by Jews and secret organizations such as Illuminates and

${ }^{51}$ See more at the IZ website: "Mekki Turabi u Sarajevu," Mesihat.org, accessed at September 172017. $<$ https://mesihat.org/2010/10/26/mekki-turabi-u-sarajevu/>.

${ }^{52}$ Aid. Smajić "Bosnia and Herzegovina (Country report)," Yearbook of Muslims in Europe. ed. Joergen S. Nielsen et al. (Leiden: Brill 2011), vol. 3, p. 110.

53 See Enes Ljevaković "Fetva o nadriljekarstvu i iscjeliteljskim seansama Turabija. “ Accessed at September 17 2017. http://www.Islamskazajednica.ba/index.php?option=com_content\&view=article\&id=11245:fet va-o-nadriljekarstvu-i-iscjeliteljskim-seansama-turabija\&catid=203\&Itemid=457 .

${ }^{54}$ Ibidum.

${ }^{55}$ E.g. preacher Semir Vatrić, "Mekki Turabi - kratko i jasno raskrinkavanje," Minber.ba: Accessed at September 17 2017. http://minber.ba/mekki-turabi-kratko-i-jasno-raskrinkavanje/.

${ }^{56}$ E.g. Archive.org. The Arrivals. Accessed at September 17 2017. https://archive.org/details/The_Arrivals. 
the Freemasons, for Dajjal (anti-Christ) against Islam and traditional societies. Its creators call for the unity of Sunnis and Shiites, Muslims and Christians under the traditional Islamic banner to fight the New World Order represented by the USA. Several episodes also portray the main arms and strategies used by the Satanic Army to reach their aim to annihilate everything pure and moral. Others cover secret signs in pop-music, architecture and art. This series was supported by in all probability the world's most famous Muslim conspiracy theorist Imran Hosein:

"I am astonished by the large number of emails I have received from those who have become Muslims, who are now attracted to Islam, or who have had their faith in Islam revived as a result of viewing The Arrivals. This is no mean achievement in this age of declining interest in religion.

A critique of The Arrivals, who is worthy of a Muslim, should therefore direct attention to the great good that has been done, even while pointing out alleged mistakes which have been made. Secondly, a critique of The Arrivals should not set out to do a demolition job, but rather alleged mistakes should be addressed constructively and with due respect for the integrity of those brothers in faith who are being corrected." 57

This very same author wrote about conspiracies, NWO and world events, supporting anti-western and pro-Russian views and during his visit to Bosnia only gave interviews to the Serbian owned televisions where he also denied the Srebrenica massacre was a crime of genocide. ${ }^{58}$ For this reason, he was strongly criticized and condemned by the prominent IZ intellectual Ahmet Alibašić on July 14 2015:

"Imran Hosein is known to the Muslim public mainly because of his controversial interpretations of world news and to the lesser extent due to his Islamic knowledge. His "analyses" are close to the conspiracy theories and, as such, are often inconsistent with facts. During his speech to Bosnians and other Muslims in the Balkans, Hosein did not honour himself by even ensuring himself about the correct date of so important an event about which he was speaking for 25 minutes." 59

\footnotetext{
${ }^{57}$ Imran Hosein, "Arrivals Series - Signs of the Last Day." Accessed at September 17 2017. http://www. imranhosein.org/faq/55-signs-of-the-last-day/208-arrivals-series.html.

${ }^{8}$ See "Šejh Imran Husein brani Srbe i negira genocid u Srebrenici" in Bosnian Times. 13. VII. 2015. Accessed atSeptember 17 2017. http://thebosniatimes.ba/clanak/850.

59 See "Profesor Ahmet Alibašić: Ko je šejh Imran Hosein kojeg srbijanski mediji koriste za negiranje genocida?" Faktor.ba. Accessed at September 17 2017. https://www.faktor.ba/vijest/ profesor-ahmet-alibasic-ko-je-sejh-imran-hosein-kojeg-srbijanski-mediji-koriste-za-negiranje-genocida-207820.
} 


\section{Sorcery and jinn encounters ${ }^{60}$ \\ The black dervish}

This case also earned publicity in neighbouring Serbia ${ }^{61}$ because the main character was a non-Muslim law student I. studying in Sarajevo. Her Muslim friend suggested she visit a sorcerer and soothsayer called black dervish (crni dervis) at a nearby local tekija ${ }^{62}$ to get to know her marks in tests. According to I., the session was just another innocent experience with that beautifully mysterious oriental ambiance. During the séance with the black dervish, I. received a zapis to be put in water for the night and was told to drink the water every morning, for a better memory. She received $8 / 10$ as the black dervish foretold, but lost her appetite, lost weight, become nervous and her head started to ache. Her mark was due to an enormous struggle and not due to a better memory. Her friend confirmed the same symptoms so they both asked help from hodža. During their visit, he clearly assigned their problem to the activity of šejtan but was concerned whether he was able to help a non-Muslim. After therapy prescribed by hodža, the Muslim girl got better but the Christian did not. She suffered from headaches and now also from fatigue, tiredness and pallidness. Her school results worsened, she lost concentration and the ability to memorize. Her mother advised her to visit a doctor (she concealed from him and her mother all her jinn history) and he diagnosed her with anaemia and chronic exhaustion with medication with no result. Then I. confided in her atheist mother who is an university graduate physicist so she did not believe her. When no medical care helped I., both women sought out help at Serbian vracarka B. of Banja Luka. She foretold madness and impotence for I. and took $2500 \mathrm{KM}$ for them but did not help them any way; the same occurred with another folk healer. I. grew worse, her self-confidence was lost and she repeatedly failed her exams. She also started to suffer from psychosomatic symptoms such as fever, shaking, stomach aches and flu symptoms for no reason. This did not stop even after relocation to Novi Sad, Serbia. She also suffered from psychosis based on the words of Banja Luka vraćarka. She even became suicidal. Finally, both the daughter and the mother, after some necessary theological preparations, were baptized again at a local Orthodox church and I. finally got rid of her symptoms at the women's monastery of Ćelije over the next three months.

\section{Seventeen years of sibr}

A., one of the visitors on the N-UM web page claims to be in possession of a jinn for 17 years since her childhood. When she was 9 years old she had a seizure of suffocation and was taken to the emergency room. The examination ended with no result and all the symptoms were ascribed to anaemia. One of the doctors knew about jinn cases and gave

\footnotetext{
${ }^{60}$ All stories mentioned in this section are sourced from online archive of N-UM web portal. See N-UM "Sihr i džini." Accesed September 17, 2017. http://www.n-um.com/category/sihr-dzini/. Whenever there is another source, it is also mentioned.

${ }^{61}$ See "Ispovest zatočenika sekti (deo III): Posrnuće verske prirode" Svet tajni. Accessed at September 17 2017. http://www.svettajni.com/vasa-prica/ispovest-zatocenika-sekti-deo-iii-posrnuce-verske-prirode/.

${ }^{62}$ Building for sufi spiritual meetings and group zikr.
} 
her a card with a morning and evening $z i k r$ to repeat. The victim was from a religious family and she relocated to a new home. Some people envied them and the family began to feel symptoms of disintegration. The victim's health problems became to worsen with suffocation and arythmia. After she grew up and began to wear a hijab, her problems diminished some what but not for long. Her health was severely affected, with blood coagulation problems so severe she could not undergone banal surgeries, had problems with pregnancy and stomach aches. The doctors were unable to identify the cause and all the liver, stomach and kidney examinations did not reveal any pathology. A psychiatrist was recommended for arythmia and suffocating seizures and there were additional problems - nightmares, voice hallucinations and total exhaustion being unable to get out of bed.

The healing was a three-year process with unclear results depending on how seriously the victim took the treatment. Her husband supported her during all of her treatment, learned how to enchant rukja, asked for advice from well-known respectable healers and consulted literature. The healers claimed the victim had suffered from several pieces of sihr, some of them very old which complicated the entire situation. One part of the treatment was to observe as much voluntary worship (reading the Qur'an, praying supererogatory prayers) as possible, which caused enormous difficulties and anxieties and to stop watching TV series and films. She also used banjanje (or hijama), massage with olive oil and drinking water with rukja. Her husband also recited her rukja every day. The massage was extremely painful for those inside her but they left her body one by one and the last communicated šehadet in front of him and said the others wanted to destroy her. After obeying, however, the rules of treatment, the problems never returned and the victim thanked Allah Almighty for the help.

\section{Female jinn and a hafiz}

N-UM wrote about the story of one deceased Sarajevo hafiz who fell in love with a beautiful woman who he saw in front of a mosque every sabah and akšam prayers. After several days he plucked up courage to talk to her. Her name was Aiša and she began to take walks with him, first around the mosque and later further and further, talking to him about various things. He felt she understood him as no other women and that she was the love of his life. He began to give her small gifts and received back something he described as a feeling of true love you can have just once in your life. During Kurban Bajram, she gave him a beautiful ancient serdžada, prayer rug. He felt he wanted just her and no one else.

Soon after, however, she began to feel sad, saying she had to break up with him. Whenever he began to tell her what they could do together, she began crying. Once at night she told him that she felt a need to touch him and he told her it was better not to since Allah prohibits it. He finally puts his right index finger used for šehadet in prayer on hers and after she closed her eyes he kissed her finger. The next day she did not come at the usual time. Hafiz thought he had lost her because he had done a prohibited thing although it did not seem to be so. The local mutevelija told him that some Aiša was looking for him 
after ikindija prayer and had left him some message on a card: "You gave me proof of your love. I left because I had to. It's better like this. Believe me. Yours Aiša."

Hafiz began to look for her but there was no track of her. The local women did not know any girl like that, either in the mosque, or in the local mahala, nor did the shopkeeper in the shop where he brought marama (hijab) for her, nor the goldsmith where he bought a golden necklace for her; no one remembered her. Once she had told him where she lived. When he arrived there, however, there was no house at all. He began to doubt his sound reason and tried to find the prayer rug she gave him to show it to old hodža Jakub-efendi, a very wise and learned man. When he brought it to him, he said: "Oh, my son, you failed quickly. This perfume is some old Persian amber, used by those who dared to do some unpleasant things with the jinn, where did you get it from?" He told him everything, even that he maybe should not have, but Jakub wanted what was best for him. He told him that he probably met a jinn girl, since she used to meet him after sabah and akšam, when the jinn gather. This is why it is not recommended to go out at that time or to sit in the door on the doorstep so as not to fall into their kolo (dance). Jakub told him these creatures are highly dangerous and take the form of the best likeness, but cannot have any intimacy with people since they are not of their kind. They can devour, however, a man's soul in parts.

Hafiz kept her serdžada and her letter until his death. The perfume was still present but the letters on the card became faded with time, except for the words "yours Aiša."

\section{The hodža's son}

Lj. N. from Belgrade spoke for the Montenegrine newspaper RevijaD about her "game with the devil"63:

"I wanted to buy the flat which I had rented for years. The price was really low and I took out a loan from the bank. But suddenly, the flat owner said he was going to sell the flat to another person as he had given him a better offer. One day, I went to visit my friend, and I saw in her flat the remains of an occult ritual - my name written on burned paper and my half-burned photo. I already knew that my friend was doing black magic to anyone who stands in her way.

After this, I heard from people, who know these things, about one sibirbaz of a Muslim religious affiliation from Bosnia who was really good at his job. I called him to make an appointment and he said to me: 'Your friend performed black magic on you, so you couldn't buy that flat.' and asked me three times if I really want this flat. He firmly promised me that the flat would be mine. As agreed, I went to his home bringing with me everything he needed for his ritual: water from the flat, part of the doorstep and photos. When I arrived, he wasn't there. His brother told me he needed to go to a hill, sleep in the grave of his father, a former hodža, as he always asked him for advice."

\footnotetext{
${ }^{63}$ See more for resources at: "Sklopila ugovor sa šejtanom," N-UM. Accessed at September 17. http:// www.n-um.com/sklopila-ugovor-sa-sejtanom/.
} 
Tomorrow, when the sibirbaz came home, he told her that everything will be done in two days, and explained what to do with the things he sent her:

"It was strange that he didn't want to take money, but I thought he was fair and and wanted to help me. He sent me water, wire and some bundles. I sprinkled water in the corners of the flat, poured water in the coffee and juice for the owner and the people who came to buy the flat. Suddenly, the owner said to them he would not sell them the flat as he had given her word to me first. I couldn't believe this turnaround. Everything was just like sihirbaz told me. I bought the flat and I thought I had finally been freed from black magic my friend did to me."

And then, nightmares and headaches began. She heard rustling inside the flat, banging of the door, footsteps:

“I started to see men's faces, someone under my blanket or taking my blanket down. I saw hands touching my breasts so strongly. I cried and turned the light on, but it didn't help. Later, ghosts started to rape me."

She said she was raped at least once per week. The gynecologist's report also confirmed the rape. She did not tell anyone about this as she did not want them to think she was crazy. Sometimes she slept at her friend's house or relative and parents' house. In the end, she told everything to her parents.

"At night, after I went to sleep I felt breath on my face and a beard scratching my skin. I had scratches all over my body. But I couldn't tell if it was done by evil ghosts."

Her parents helped her as they asked one vračara for advice. Mage told her that everything which was happening was the result of an agreement with evil ghosts invoked by a sihirbaz from Bosnia.

"I was shaking when she told me that God saved me from a black mage who wanted to raped me, but he was disrupted as I came in his absence. Words she told me still resound in my brain: 'If you met him, you wouldn't come home. He would rape you in the grave of his father where he sometimes finds help, and you would fall in love with him.

She told me she did not have the power to fight against him as a black mage is much more stronger than a white mage. She didn't drive them out of my flat, but somehow she stopped the rape. I know they are here, but they don't mistreat me like before. I was thinking about going to a monastery and asking for help. I read in literature about how to drive the devil out. This is not against religion."

She still sleeps with garlic, lights tar, the incense of kandilo and smokes out the flat.

\section{Negative love magic}

Raki (spiritual healer) E. B. shared with N-UM this story:

"A young Muslim man was in a relationship for two years until problems suddenly started. He acted very strange and they broke up. He couldn't help himself, feeling weak and powerless. He tried to go to sihirbaz at the beginning of Ramadan, but was rejected as the sihirbaz did not work during Ramadan. Once during taraweeh prayer, he felt his hands shaking while listening to the Qur'an, and began to suspect sibr. He contacted raki E. B. 
and made an appointment. When they met, the healer told him he should use fragrance and recite from the Qur'an. As soon as he met the healer, he experienced a really strong smell (jinns cannot stand a pleasant fragrance). The healer acted normal, but the friend who came with this man was really scared. After an hour and a half of reciting the Qur'an, the healer was tired, and the jinn more aggressive. The young man opened his eyes, and the jinn reaction was still there. He couldn't control it. Then the healer gave him the water over which he recited the Qur'an first. And then the jinn started talking.

The healer knew the jinn was hard and aggressive, so he continued reciting the Qur'an. The young man started to get up, but something or someone pulled him back. Again, the jinn talked, and the healer asked why he was here, for how long, how he got into him, and if he was scared. The jinn said he want to separate this young man from his girlfriend and had been trying this for two years. He also said he was scared of sihirbaz. In this conversation between the jinn and the healer, the jinn also said he would not go out of this person. And the healer continued with the reciting. The young man cried and screamed, and when the healer put the fragrance closer to him, the jinn told he would go out from the mouth, from the same place where he got into him. At that moment, the young man began to vomit and felt much better. He drank same water, and smelled the same fragrance and everything was fine. It was pleasant for him.

After one month and one extra healing treatment, this young man became reconciled with his girlfriend, and now they have been married for several months."

\section{He converted to Islam because of sibr healing}

Jusuf, a Serb convert, told N-UM his story:

"I went with my girlfriend and her mother to the vračara. I always knew there was a God, but never obeyed. I believed it was enough to have an icon, frankincense and a cross at home. This vračara did some black magic and my life turned upside down. After a certain period I broke up with my girlfriend, but I still didn't feel good.

I started to go to church, but the situation was the same. My priest friend told me there was one black hodža who could help me. He was surprised about this as he knew there were Muslims in his place. Then he remembered how happy he had been when he used to listen to Bajram preach on TV.

Hodža asked for my name, my date of birth and my mother's maiden name, and said we should come to visit him, as I was in a really bad situation. When he came, he was a nice and kind man. He told us about Islam. I accepted that there is only one God, that Jesus in not His son, but His messenger. Then he took black Mushaf. It seemed like he was praying, moving his head up and down, left down, and at the end he drooped Mushaf. The book opened to one page and here the drama began. He told them about things which only I knew about. The hodža gave me zapis.

From this time, everything was good for some period. Soon, disasters began to happen; a loss of wealth, honor and a family in troubles. I called the hodža again to come to my home. After he came, he did the same thing as before. He also refused money saying he 
did not sell God. When hodža looked into a book of my sister, he said she would die, but he could prevent it if they paid him 2,800 euros. I sent it in Novi Pazar. There he told he would pray for us, and at the end the money would come back like zakah to us. Hodža burned some soil on the kitchen range, and gave us some water to drink and to take a bath in. He asked for our fingernails and hair to heal us. This was suspicious for Mother that the money still had not come back to us, but we continued to borrow money from people. The amount was over 6000 euros in the end. After this, everything got even worst. The family was fighting and he started to tell me things which made me hate my mother.

I read the Qur'an and I read that they don't give zakah to people who have debts. Hodža got angry and didn't communicate with us for while. I went to masjid and there I found the truth. I called hodža and told him I want my money back. I also said I converted to Islam, but hodža didn't believe me. We still haven't got our money back. I have been a Muslim for four years and am still paying off the debts."

\section{Sibr of envy}

A married couple came to raki E. B. from Central Bosnia for rukja. They were Muslim believers, of middle age, quite wealthy. Raki told N-UM:

"They grew sick suddenly. They cured one sickness, and another followed. After a few sessions of rukja, one of them lost consciousness and the jinn started to talk. The healer asked him where sihr was hidden, and he showed him to a corner of the flat, where there was one big vase with a kind of flower which lived for several years. The jinn also said that this sihr was made by the wife of their best friend. She brought a small bottle with mrtvackka $v o d a^{64}$ and blood. She poured all of this into the vase with the flower. She admitted everything and the flower was destroyed. The reason for this sihr was envy. The married couple grew closer to one other and even did hajj."

\section{She repented for carrying out sibr on her ex-boyfriend}

One user asked Prof. A. Kuduzović, one of the senior Bosniak graduates from a Saudi university, the following question:

"After her boyfriend left her, she never get over it. He married one of her friends. They had a happy marriage, until she decided to ruin it. She went to one hodża, and paid him to make $s i h r$ for them. After it was ready, she put the sihr in their food.

Problems and fights soon began to happen. The wife was desperate, he started to leave the house more often, and even started to drink alcohol. As time passed, this women started to feel guilty for what she had done to them, even more so after they had a child.

She decided she wanted to bring and end to it, and asked how. She was told she had committed a grave sin in Islam, the kind of sin that if you do it you are no longer a Muslim. If you truly repent, however, God can forgive you. This sihr can only be stopped by rukja healing, and she should make a major effort to convince them to pursue this kind of healing."

${ }^{64} \mathrm{~A}$ kind of magical water after ritual washing a deceased person, believed to be harmful and bring destruction. 


\section{At the edge of life}

One Bosnian family, with no previous history of such a kind, began to experience problems: sickness, loss of wealth, quarrels. The medical results were fine, but the family was still "at the edge of life". They called a healer and made an appointment. He recited the Qur'an to them and also said:

"The reactions were horrible: jumping, screaming, falling down, a state similar to unconsciousness, vomiting. After reciting rukja, I gave them therapy of healing: fulfilling Muslim obligations, avoiding haram things. I recited rukja with black seed oil, honey and water. I told them to sprinkle water in corners of house since jinns find it smelly and it burns them. They should also try to find sihr at home.

After they searched the entire flat they found some kind of figure with zapis in the mattress in the bedroom. The zapis was sihirbaz's order for the jinns to attack this family. They found a clump of hair on the curtain. The healer told them to burn the hair, starting by mentioning God's name. When doing so the wife began to vomit, behave aggressively and scream.

Her friend stole a comb with hair, or only hair, and gave it to sihirbaz as she was envious and full of hate."

\section{The father was possessed 20 years ago}

N-UM quotes from a book by Vahid Abdusselam Bali:

"One man came and told there was a jinn inside his father who was 45 years old. During the hutba ${ }^{65}$ he lost consciousness, sometimes during prayer as well. Every Monday, he locked himself in a dark room and slept there alone. One healer came to him with his friends and asked him what the problem was. He said he felt like he had a female jinn inside of him, and he wanted to get rid of her. The healer told him to go and make ablutions, and all the others did the same. One of the healer's friend started to recite rukja, and the body of this man started to shake. This was a sign the jinn was there, so he started a conversation with her. The female jinn said she was not a believer, and she came to revenge her jinn relative as this old man beat him during one rukja. She met him in one empty street, went inside him and she had been inside this man for 20 years. The healer told her to convert to Islam which she did.

Then, he asked her to leave this man, which she refused as she was in love with him, and every Monday they had intercourse. In a dream, he sees her as a beautiful lady, and in the morning he would see the remains of his sperm. The second reason she did not want to leave this man was Islam. Her kids were unbelievers. If they found out she is a Muslim, they would kill her. The healer told her this man did not want her, and if her kids wanted to kill her, she could find another place to live. She accepted leaving in the end, but lied. The healer could see it in his eyes. The healer's friends began to recite rukja again, and she again spoke out. She said she did not want to leave him as she really loved him. The healer

${ }^{65}$ Friday sermon. 
said he would use beating and burning if she refused again. She said the name of this man two times, and left his body. This jinn was from those living in sea water in the Red Sea."

\section{Sibr caused her mental disease}

A young Muslim girl, 21, called a healer and asked him for help. After he met her and her father, he saw on her face sorrow, pain and powerless. She looked skinny and sick. Her family were not practicing Muslims, and they lived in a non-Muslim town. She said she was taking pills and sometimes she visited a psychiatrist. Her father was a police officer, and said he would do anything to cure his daughter. They visited the most famous doctors and sihirbazs, but nothing helped. She only felt even worse and she was taking pills which were damaging her brain.

A.B. (the healer) described her case:

"After this conversation, I started to recite the Qur'an. Soon the jinn appeared. He was Jewish. He was so powerful. I did not talk too much with him and just continued to recite the Qur'an. I stopped after half hour and gave therapy to her, and advised them to fulfill Islamic obligations, like prayer.

After three weeks, they came again. I saw good results. I started to recite the Qur'an again, and the jinn appeared, but this time he was weak and not so arrogant. I ordered him to convert to Islam which he initially refused, but after I insisted, the jinn accepted Islam, and he said this girl ate sihr, and he also said he was in love with her. They use to have sexual intercourse every night. I told him to fear God, to leave the body of the girl. He obeyed and left.

After a few days the girl called me again. She told me they had visited a lot of sibirbazs. Those kind of people who offered many different kinds of healing. One even asked her to sleep with him.

Today, this girl is married, wearing a hijab. She is a practicing Muslim along with her family."

\section{$A$ haunted house}

A healer from Macedonia known to N-UM website was called, late at night, to come to a house. The house was familiar to him. Many families moved there, but soon left. He had heard that the house was haunted. This is what he saw:

"When he arrived, he saw six women holding and trying to calm one young girl. $\mathrm{He}$ told them to leave the room, and only her parents could stay. Girl looked crazy, crying, rubbing her hair and screaming. The healer asked her mother how long she had been acting like this, and here mother said from aksam prayer up until now. It was 2 in the morning.

After the healer's question about what happened here and whether they had had problems like this before, the mother said they were just sitting in the room when the girl ran in. Her head and hair moved like someone was kicking her in the face. Then she threw herself on the bed, closed her eyes and just repeated that they were in the room and wanted to kill her. 
Mother said she used to see shadows, and once she saw a small, ugly person that looked like a woman. Sometimes, things would disappear. While they were sleeping, they heard steps, sounds of opening a door, or tinnitus in their ears, or a sound like someone was moving a pillow when they were sleeping.

The healer told the father to hold the daughter, put a blanket over her and cover her head with a scarf. He told the mother to take wudu and listen to rukja. He started to recite the Qur'an and the girl screamed more and more. Then he recited the Qur'an over water, sprinkled it all over the room, and then put a wet rag over her eyes. After this, he began to recite $z i k r$, and this affected the girl like someone cutting her with a knife, screaming even more. The mother was calm and did not have any reactions. The father continued to hold the girl while she was repeating that they were in the room and and that they were going to kill her. Then the healer recited athan, and the girl grew calm for a bit. When he recited surah al-Fatiha, especially the last ayah, she screamed, so he recited it louder and louder. At one moment, the girl told the father they were on the wall, all of them were with a cross. The healer sprinkled water on the wall, and the girl said she could not see them anymore, but she felt like they were inside her as her legs were tightened so hard she could not even feel them. The healer asked if she felt pain in her stomach, the answer was positive, so he gave her more water to drink and continued to recite the Qur'an. Suddenly, a rough voice spoke from the girl and said to stop the reciting as they wanted to leave her. The healer asked the girl whose voice this was, and she said it was a young man who she used to dream about and that now his left side was burned because of the water and reciting of the Qur'an. The healer asked if there was someone else inside her body, and the voice said his brothers were there, also burned, and that they wanted to leave too. The voice said they lived in this house, but this family was bothering them, and they would not leave this house, or anyone who lives here in peace. The voice also said his parents and relatives were out, and they were telling them to leave this girl. The healer explained to them that God created human beings and jinns. All of them have their world, and it is prohibited to mix between worlds. They did not want to talk any longer, but just wanted to leave.

The jinns were Christians, so the healer called them to Islam, but they refused as their parents would not allow this. They only wanted to leave this girl, and that was the healer's aim. The healer told them to go out, to leave this place and this family in peace, and he started to recite the Qur'an.

The girl removed the rug from her eyes, and looked at her hand which started to lift up. The healer asked if they were in the hand, and the girl just said she could not feel her hand. Then he stabbed her finger with needle, a bit of blood flowed, and the girl fell down.

She looked very tired and started to cry, but there was no longer fear in her eyes. The healer asked her how this started and she said jinns used to come in her room to take some things and bother her. She couldn't tell anyone about this as they threatened her in dreams that they would kill her. That day, at magreeb time, they attacked her, starting to beat her face and back. She felt some bad smell enter her mouth, which choked her inside until the healer came and drove them out. 
The healer advised the family to throw away all the pictures and decorations with the shape of human beings. They played surah al-Baqarah once per day. They he left, sprinkled water in every corner of the house, outside and inside, and every corner of the yard."

\section{Mother and children attacked by "something"}

One user wrote N-UM:

"One boy, 14 years old, called his mother after midnight to come to him. He cried, and told her that he went to sleep, but someone told him to go to masjid. He turned on the other side and tried to sleep again, but something grabbed him and threw him on his back. After he opened his eyes, he saw something black on his breast which tried to choke him. His mother told him it was only a dream, played him rukja on the computer and went to sleep.

Suddenly, she was sleeping and dreaming her daughter was falling down. She woke up, but it was as if she was still asleep. She heard rukja from the computer, but she couldn't move. She was present, but it as if she was not. Her mouth was open wide but she could not breath. She tried to call out to her husband, but the voice was not hers. Her jaw was stiff and some voice was coming out of her mouth. She heard someone speaking in a language she did not understand, like it was Arabic, but it was not. She still heard rukja, but it was impossible to talk. She tried her best to say shahadah, but she couldn't. She only heard a whining and howling, and a voice coming from her like -aaa aa aaa-.

Something pushed her breasts, hands and legs. All her body went numb. Somehow, she found the power to say shahadah, and at this moment the pressure disappeared. She was tired, and just called her husband to turn off rukja.

She used to listen to rukja before, but nothing happened until she experienced a sick feeling, later a pain in her stomach, sorrow, crying and choking. Her last reaction was this, and after this she was scared to listen to rukja if there was no healer present."

\section{An unknown lover}

A non-Muslim, young mother to a 5-year-old daughter, confessed to N-UM that she had a problem with an unknown "lover". He was not a human being, but someone from "the other side". When she talked with her Muslim friend she found out it was a jinn:

"Muslim jinns or disbelieving jinns, they live with us, but we are from two different worlds. They have their life, and we have our life. We don't bother each other, but sometimes because of a person's inattention, jinns can attack a person. This kind of attack is called possession. The worst kind of possession is a jinn "lover". He attacks a person, and doesn't want to leave that body as he is in love with that person. In this case, jinns can have sexual intercourse with people, in dreams or in reality. He often rapes the attacked person.

Symptoms of obsession by a jinn lover include ejaculating while sleeping, a sudden desire, sexual and marital life disorders for no reason, frigidity, pain in the genital organs or in the abdomen, insomnia and olfactory hallucinations. It can be stopped by using 
fragrances on the genital organs, especially black musk, fragrances on the clothes you sleep in, zikr, not sinning ..."

\section{Something was moving fast inside his body}

One man went with his friend to a healer, as his friend had problems with dreams and wanted the healer to recite rukja to him. Raki described the following:

"This man, with one more person, wanted to be present during the healing. I started to recite rukja, and this man closed his eyes and felt a little upset and nervous. Soon, he heard someone fall down, but he tried to concentrate on reciting, but he felt his legs swinging. After a few minutes, his entire body was swinging, and he knew something was happening. He couldn't control his body anymore, and the people around him tried to make him lie down. Then he felt something moving very fast inside his body.

I continued to recite rukja and this man had even worst reactions like shaking and screaming, opening his mouth very wide, and he felt something unhinge from the deep of his stomach. His mouth opened wider and was followed by scary scream. Suddenly, his body calmed and he felt he could open his eyes and and experienced a major relief."

\section{A personal encounter and semistructured interview with a raqi - spiritual healer}

The author of this article met the spiritual healer F. from North-Eastern Bosnia in January 2018. F. is a man in his forties, married, with several children, self-employed in selling honey and agricultural products of his own production. He lives in a community of alternative salafi believers in a small village. F. agreed to a short semi-structured interview where he responded:

1. I was not a practicing believer from the beginning, my family were not strong believers but after the war I met some brothers near shaykh Jusuf ${ }^{66}$ and I began to study Islam under them. I then began to specialize in Qur'anic healing. I wanted to help people.

2. I only use Qur'anic verses and authentic rukja, sometimes I enchant rukja with water, honey or oil to be further used. I do not use herbs, hijama or anything like that because I am not well-versed in this field.

3. There are plenty of cold rakis and folk healers but the majority of them they do not know what the authentic Islamic method is. They do not care about halal and haram, they touch women and speak with the jinn, or use amulets, etc. All of this is un-Islamic.

4. I am not against conventional medicine at all, or against doctors. I also know some of them. I just say I can also help since there are cases medicine cannot cure. The majority of my patients use medical and spiritual treatment at the same time. And whenever I

\footnotetext{
${ }^{66}$ The subject relates to Jusuf Barčić (1965-2007), one of the leading Islamic scholars of salafi movement in after-war Bosnia, graduate of Sarajevo Gazi Husrev Beg's medresa and Islamic university of Medina, who died under mysterious circumstances.
} 
cannot help, I send patients to a doctor. There should be better cooperation, we should advice each other.

Some people try just one method but we can save more people using both.

1. I say the jinn also causes illnesses such as bacteria and viruses do, sometimes they are behind some unexplained cases. With the destruction of the environment and improper behaviour, disrespect for nature and the teaching of Islam we come more into contact with them and they can affect us. Sometimes people visit me and they suspect jinn but they turn out in the end to be completely clean. Nothing was there.

2. On the other hand, for example, I noticed that all of my patients who were also under oncological treatment, also had a jinn problem. I cannot say whether the jinn caused the cancer or whether people with cancer are more vulnerable to a jinn attack or possession. The majority of people with cancer never come to me so I will never know, but everyone who I treated, they had some sort of jinn problem as well. I believe there is some connection between the two.

\section{Analysis of key elements and their possible interpretations}

A. When it comes to the cursed buildings, there is the ancestral motive of a missing sacrifice and there is a horrible compensation in both of the cases. Both of cases also provide more explanations by the participant themselves based on their own spirituality, religious affiliation and feelings, from forms of modern western ghost stories to Islamic explanations of a jinn and/or punishment for not fulfilling certain obligations. In both cases, there is a strong connection with death and dead people, in both cases killed in an unnatural way - executed, tortured, etc. In both cases, the Islamic motives are dismissed when the cases were referred to the non-Muslim media. The participants tended to shift their explanations and change them in a way to fit to the expectations of the questioners. Using this mechanism, the story about cursed places can be transmitted further and live its own life.

B. Both the cases of celebrated foreign folk healers and writers on jinn and sorcery uncover a gap between the laymen, on the one hand, and scholars on the other (both local traditionalist and foreign salafi provenience). Their demand for purity of belief collides with the demands of people for a more vivid, spontaneous form of religiosity, which can also be clarified using a cognitive approach by Whitehouse's thesis on the two modes of religiosity and religious experience - one more contemplative and the other more ecstatic. ${ }^{67}$

C. The rukja stories provide us with deeper insight in the reality of magic practices in Bosnia (according to the coding scheme):

${ }^{67}$ Harvey Whitehouse, "Modes of Religiosity and the Cognitive Science of Religion," MTTR 16 (2004), 321-336. 
1. The victims are nearly in all cases (14 out of 15 , e.g. $93.3 \%$ ) except one (the wealthy married couple) young people under 30 years or even children under 15 (even the older patients said they had suffered from a young age) - either because of the prevalence of such cases or because of the sample used. Young people use the Internet more and like to read about young people, $60 \%$ of them were women or pairs where the woman was more severely affected. One case was a couple and the rest were men. In terms of religious affiliation, there was a quite surprisingly high number of non-Muslim victims (3, e.g. 20\%), one of them even being a convert to Islam, the second deepening her own religiosity or beginning to believe (identity defence). There was no prevailing occupation of the victims and the stories mostly even do not report it. The vast majority of the victims $(87 \%)$ do not have any prerequisite knowledge or other history of a similar experience and in all of them the problems started suddenly.

2. The symptoms they report vary widely, usually being exhaustion, nausea, fatigue, headaches or psychosomatic pains typically with no medical explanation. They tend to worsen and deepen with time, with a duration from a month to decades. The typical patterns are severe seizures, shaking and loss of consciousness or control while praying or reciting the Qur'an. This pattern is a key factor for the spiritual healers to diagnose the spiritual nature of the disease. Medical experts diagnose exhaustion, epilepsy, depression or anaemia in most cases.

3. Cases of the evil eye are quite frequent in field research but do not appear in our stories from the web mainly because of their triviality. Witness reports published composed $53.3 \%$ of sihr or magical attack, $13.3 \%$ of cases were jinn touching or attacking people with a different intensity and $36.3 \%$ possession cases. The source literature speaks about touchings and attacks as more common than true possessions - those were considered quite rare. Again, most of the touching and attack cases were certainly unpublished.

4. The causes behind the incidents differ widely. Relatively common was sihr without a specified reason $(26.6 \%)$, than marital subversions, love possessions and possessions without a specified reason (13.3\%). Sexual subjugation by sibirbaz, jinn touching out of love, sihr of envy, attacks for an uncertain reason and a combination of sihr and love possession of a jinn were more rare (6.6\%). The main kind of sihr was zapis or unspecified, once hair from a comb and mrtvačka voda was used.

5. The most common in nearly all the cases is healing method by reciting the Qur'an and $z i k r$ - rukja by the healer, this being often the only method (60\%). This method is usually the main pillar of treatment, combined by obedience to Islamic teachings and abstinence from sinning. In terms of material treatment, fragrances, incenses, frankincense, garlic, water (with enchanted rukja) sprinkled in corners, oil (with enchanted rukja) and hijama were used each in one report. In the Orthodox Christian context, treatment was by means of the Orthodox liturgy. In three cases (20\%), there was another sihr used as a means of treatment of the previous one, but without any effect.

6. In most cases $(80 \%)$ the healers do not indulge in long communication with other worlds, just ask the jinn to leave their hosts or confirm there was sihr and where it is. 
In the minority of cases they were asked for further details like their names, religious affiliation or the place where they live.

7. The dichotomy between the proper Islamic spiritual healer raki and the heterodox sihirbaz is maintained. Both categories usually do not mix. Sihirbaz is sometimes nicknamed as hodža or dervish but from the context it is clear that the person is quite different from an ordinary religious specialist or sufi. This difference is often underlined by the attribute of blackness or darkness. Sihirbaz also appears as an imposer who takes money from the people or brings them other problems without helping them.

D. Lastly, the author's encounter with a salafi raki is an interesting case of self-identification in terms of what it is like to be a Bosnian salafi raki and how this person defines himself in terms of interaction and critique of other competing people and their multiple identities; different from medics, folk healers and the local religious authorities.

\section{Conclusion}

The idea of spiritual healing, sorcery and related phenomena and folk superstitions being suppressed by secular modernity in the early twentieth century and subsequent Communist regimes over the long term cannot explain all the specifics and particularities of the Bosnian encounter with Islam (and Islamically influenced magic as well) as documented by the Pew poll. It differs substantially not only from the rest of the world but also from the rest of Post-Communist Europe and from Turkey with its aggressive secular past (generally a lower number than the world average, but higher than in the non-Muslim dominated secular Marxist regimes in the former USSR, Yugoslavia and Hoxha's Albania). The qualitative difference between the Communist rule in Enver Hoxha's Albania and the Soviet Union on the one hand and between Josip Broz Tito's Yugoslavia on the other is also not a clue, since there are certain questions setting Tito's Kosovo and Stalinist Albania apart from Bosnia. Belief in jinns is relatively higher in Bosnia and in Russia, where the regimes tried to co-opt certain Islamic structures in the state structure (like IZ of Muftiyat of Russia) as opposed to Albania (23\%) where Hoxha's regime waged war against everything religious. The situation is the opposite in case of sorcery, it being viewed as backward by the state authorities and as a heresy by the religious establishment. In the case of the evil eye, Kosovo and Bosnia manifest lower numbers than Russia and Albania, as the religious establishment in former Yugoslavia tended more to a rationalist stream of Islam than to local traditionalism with a strong sufi influence (as has been the Russian case). Albania also stands out with talisman support (39\%, three times higher than in Bosnia and significantly higher than in Albanian speaking Kosovo - 23\%), as the only way for religion to survive was in folk unofficial practice. The same applies to the case of traditional healers (38\% for Albania, 23\% for Kosovo and 16\% for Bosnia) and in this case the Turkish example also fits the theory, there being a heavily organized religious structure in Turkey in comparison 
with formal Soviet Central Asia. This could be responsible for the significantly lower support $(25 \%$, the same as in Kosovo) for traditional healers as compared with Kazakhstan $(36 \%)$ or Tajikistan $(66 \%){ }^{68}$

The author of this article argues that the explanation could be the mix of all the aforementioned factors, together with the strong presence of an internal factor: a unique, centralized and hierarchically structured official representative in the life of Islamic Bosnia - the institution of Islamska zajednica (Islamic Community). Islamska zajednica has held a monopoly in interpretation of Islam since the Austro-Hungarian epoch. The Pew Poll clearly documents $75 \%$ of Muslims in Bosnia to believe there is only one interpretation of Islam with no other alternatives, which is the third highest number worldwide (after Egypt with 78\% and Tajikistan and Jordan with 76\%). ${ }^{69}$ Since its early days, this institution has spread a message of pro-modern and rationalist interpretation of Islam in an organized manner, supervising the work of the religious scholarly establishment and deputizing even the local imams. As early as the 1920s to the 1950s, represented by the works of the celebrated reises (head of IZ), such as Husein ef. Đozo, IZ set the agenda of a rationalist approach analogical to Egyptian Modernist movement figures such as Muhammad 'Abduh and Jamaluddin Afghani, which is overwhelmingly sceptical towards phenomena of sorcery and spiritual healing. Đozo (living at the beginning of the Communist period) stated, for example, about folk religious practices of his day:

"[Such a person] turns to the idols to ask them just like a person of jahiliya. The fact that these idols' name are not Lat or Uzza anymore, is of no importance. Their names are the grave, tomb, shaykh, murshid, zapis, hamajlija, etc."70

Concerning folk sufi healers he utters a critique:

"Like he could even resurrect the dead, not only heal the ill."

About Qur'an usage:

"[This book] is turned into a talisman, recited over the dead, whenever recited to the living, it is just for the melody and musical sound (...) The Muslims use it for zapis, for soothsaying, enchantment and other sorcery and for any means for that for what it was revealed." ${ }^{2}$

During the Austro-Hungarian era, royal Yugoslavia and the Communist time this structure worked rather in synergism than in opposition against the ruling regime and adopted toward it an adaptive rather than a resistant strategy. Due to the dominance of IZ in Islamic discourse, there was barely no refuge for official and more literalistic interpretations of jinns and related phenomena and there exists a substantial gap in this area of Islamic knowledge and the distance between leading authorities of IZ and common believers seems to be painfully wide. City-based intellectual Islam of Sarajevo's FIN (Fakultet

\footnotetext{
${ }^{68}$ Lugo, The World's Muslims, 69-80.

${ }^{69}$ Lugo, The World's Muslims, 85.

${ }^{70}$ Husein Đozo, Islam u vremenu. (Sarajevo: Izvrštni odbor Udruženja ilmije u SR BiH, 1976), 192.

${ }^{71}$ Ibidum.

72 Ibidum.
} 
Islamskih nauka, The Faculty of Islamic Sciences) is very different from folk heterodox practices of vraćari and stravarke of the Bosna valley (north-east), Podrinje (eastern border region), or Krajina (far remote north-west frontier of Bosnia) and other rural areas, which is a remarkable form of religiosity on its own. The issues elaborated above turned further into more identitarian and folk versions, and were consequently under suspicion for both secular and religious institutions. This paradigm of struggle between the Modernist and traditionalists now returns with the change in the social paradigm and postmodern tendencies of criticism of all institutions, especially of institutionalized religiosity. Bosnia is not the exception, rather the Bosniaks behave in a typically western manner - their religiosity (and approach to Islam) is decentralized with an inclination towards personal eclecticism and new, previously uncommon alternatives. In our cases these seemed to be more exotic and coming from outside, this being deeply embedded in the recent Islamic revival. There also exists a very apparent quest for identity and identitarian usage of Islam - further fueled by the very smooth language difference between them and the Catholic Croatian and Orthodox Serb neighbours, and the tendency to build it actively according to what is widely considered appropriated. This means, in the light of this assumption, that things can have more interpretations in relation to who is presenting and interpreting them to whom. Bosniaks see themselves as European autochtonous Muslims of Slavo-Illyrian descent, both as part of liberal-secular Europe and the formal Ottoman cultural milieu. Bosnian Islam therefore reacts and interacts with the wider Muslim and wider European contexts and its challenges, turbulences and sociological processes.

These trends are even more enforced by the new political situation in the Balkans, as the inhabitants have more opportunities to travel and study abroad - namely to the classical centres of higher Islamic education in Saudi Arabia, Egypt, Turkey and other predominantly Muslim countries. The number of Bosniaks studying Islam abroad at present exceeds anything in the past. The spiritual and cultural relations between Bosnia and the rest of the Islamic world are now stronger and the assumption of Bosnian Islamic streams being equivalent to the main Islamic streams worldwide is even more valid. There also exists, however, a strong connection to the rest of the Europe especially via the strong and numerous Bosnian diaspora in German speaking countries and in the USA. As can be observed, several significant patterns of Islamic religiosity adapted to secular milieu were borrowed from this direction, mainly in terms of how to organize, how to plan and how to advertise activities in this domain of Islam. At the same time local rural forms lost their formal strength with the termination of family traditional transmission with ongoing secularization and also the painful relocation of inhabitants during and after the last war (this having crushed the traditional rural communities), but leaving free space to the specific and peculiar demands of common believers with a very superficial and limited contact to local Islamic scholars. Such commoners and laymen turn to alternative Islamic streams from the global market of ideas. Due to the directions and vectors mentioned above, living Islam in Bosnia is changing vividly in front of the observer's eyes. 
The fact of the foreign influence by world Muslim mass culture is also clearly seen not only by the visits of world famous sorcerers or authors writing or speaking on the topic of jinns and sihrs (such as Turabi or Hosein) but by quite common translations of several popular pieces on the subject, e.g. Davud's Secret link between Dajjal, Bermuda Triangle and UFO, ${ }^{73}$ or the interview with a jinn by the same author. ${ }^{74}$ These kinds of books were condemned by the pro-salafi NGOs as unauthentic. ${ }^{75}$ In this respect, the new alternative Islamic narrative they represent, remained in support with local city-based intellectual rationalist Islam against the local rural-based forms and their global outreach.

The situation can also be interpreted in terms of the events and phenomena people meet and ask for their explanations. The possible explanations compete with one another in the public space in the ambient of liquid modernity. The local Islamic authorities, represented by IZ, are now still holding a monopoly for interpretation of Islam and are now also defending something they describe as Bosniak Islamic tradition, a vague term they define in their struggle for uniqueness against everything coming from outside. In this process, they are either pushed to the same side as some folk practitioners, despite the fact they once condemned them, or are on the same side as the pro-salafi circles and NGOs they are now trying to suppress because of the harsh competition in the field of interpreting Islam and the Bosnian Islamic experience. The issue of jinns and sorcery was considered for a long time within local scholarly circles a kind of common superstition and pro-salafi newcomers were the first who struggled to try to tame these practices to the strict order of Sharia. As a result the interpretation of key problems - and jinns and sorcery is clearly one of them - became a battleground for power. This struggle for the future appearance of Bosniak Islam is part of a wider concern in consent making policy since the Islamic part of Bosniak identity is one of the most significant and since other historical and cultural differences from other Southern Slavs are not as profound. In fact, Islam is here far more of a key factor than in the Albanian or Balkan Turkish contexts.

This enables the identity factor to be the main criterion in the people's consideration of which of the provided explanations or opinions on the certain cases or experiences is the most correct, while also being the reason behind the existence of multiple explanations of the same events. The function, both regarding the explanation and the identity-making, is the key factor in the successful survival of certain practices or beliefs, or in other words, the more the practice or belief is suitable for building Bosniak and Muslim identity, the more likely it will survive and spread further.

When considering all these arguments and the recent picture of a European country restoring its relationships both with Europe and the Muslim world, we cannot escape the

\footnotetext{
${ }^{73}$ Muhammed Isa Davud, Tajna veza - tajne niti između Mesiha Dedžala, misterije Bermudskog trokuta $i$ letećih tanjira. Translated by Mahmut Karalić. (Sarajevo: Libris, 2007).

${ }^{74}$ Muhammed Isa Davud. Razgovor sa džinom Muslimanom, (Sarajevo: Libris, 2008) http://Islambih.net/ knjige/book_razgovor/rsdm_00.html.

75 See Ljakić, Zijad. Knjiga "Razgovor sa džinom Muslimanom.” Accessed at September 17 2017. https:// www.n-um.com/knjiga-razgovor-sa-dzinom-Muslimanom/.
} 
problem of what the author of this article describes as mass Islam or pop Islam - the postmodern collapse of authority in terms of science, morals, religion and media, a deepening individualism, individual religiosity and a lack of ability to distinguish between facts, interpretations and personal opinions, as well as the liberal market of ideas on a global scale and identitarianist needs to assume a definite attitude towards globalism structures and the new form of empirical religiosity of urbanized Muslims with (at least) a basic education. It is no longer the scholars in traditional centres of Islamic education, but the common laymen who decide what they will discuss or write about or make films.

\section{Bibliography}

\section{Written sources}

Đozo, Husein. Islam u vremenu. Sarajevo: Izvrštni odbor Udruženja ilmije u SR BiH, 1976.

Davud, Muhammed Isa. Tajna veza - tajne niti izmedu Mesiha Dedžala, misterije Bermudskog trokuta i letećĭh tanjira. Translated by Mahmut Karalić. Sarajevo: Libris, 2007.

\section{Internet links:}

Archive.org. The Arrivals. Accessed at September 17 2017. https://archive.org/details/The_Arrivals.

Davud, Muhammed Isa. Razgovor sa džinom Muslimanom. Sarajevo: Libris, 2008. http://Islambih.net/ knjige/book_razgovor/rsdm_00.html.

Hosein, Imran "Arrivals Series - Signs of the Last Day." Accessed at September 17 2017. http://www.imranhosein.org/faq/55-signs-of-the-last-day/208-arrivals-series.html.

"Ispovest zatočenika sekti (deo III): Posrnuće verske prirode" Svet tajni. Accessed at September 172017. http://www.svettajni.com/vasa-prica/ispovest-zatocenika-sekti-deo-iii-posrnuce-verske-prirode/.

Ljakić, Zijad. "Knjiga "Razgovor sa džinom Muslimanom," N-UM. Accesed September 17, 2017. https:// www.n-um.com/knjiga-razgovor-sa-dzinom-Muslimanom/.

Ljevaković, Enes "Fetva o nadriljekarstvu i iscjeliteljskim seansama Turabija. “ Accessed at September 17 2017. http://www.Islamskazajednica.ba/index.php?option=com_content\&view=article\&id=11245:fetva-onadriljekarstvu-i-iscjeliteljskim-seansama-turabija\&catid $=203 \&$ Itemid $=457$.

"Mekki Turabi u Sarajevu." Mesihat.org. Accessed at September 17 2017. https://mesihat.org/2010/10/26/ mekki-turabi-u-sarajevu/.

N-UM. “Sihr i džini." Accesed September 17, 2017. http://www.n-um.com/category/sihr-dzini/

"Profesor Ahmet Alibašić: Ko je šejh Imran Hosein kojeg srbijanski mediji koriste za negiranje genocida?" Faktor.ba. Accessed at September 17 2017. https://www.faktor.ba/vijest/ profesor-ahmet-alibasic-ko-je-sejh-imran-hosein-kojeg-srbijanski-mediji-koriste-za-negiranje-genocida-207820.

"Svjedočanstva mještana o "Kući duhova" u Todorovu." VK Portal. Accessed at September 16 2017. http:// www.vkportal.ba/svjedocanstva-mjestana-o-kuci-duhova-u-todorovu-foto/.

"Šejh Imran Husein brani Srbe i negira genocid u Srebrenici." The Bosnian Times. Accessed at September 17 2017. http://thebosniatimes.ba/clanak/850. 
"Ukleta mjesta u BiH: Duhovi, ubistva i čudne pojave." Svet Tajni. Accessed at September 16 2017. http:// www.svettajni.com/paranormalne/ukleta-mesta-u-bih-duhovi-ubistva-i-cudne-pojave/.

Vatrić, Semir “Mekki Turabi - kratko i jasno raskrinkavanje.” Minber.ba. Accessed at September 172017. http://minber.ba/mekki-turabi-kratko-i-jasno-raskrinkavanje/.

“Zona sumraka: Istina, mitovi i legende o prokletstvu Viječnice.” Slobodna Bosna. Accessed at September 16 2017. https://www.slobodna-bosna.ba/vijest/2638/zona_sumraka_istina_mitovi_i_legende_o_prokletstvu_vijecnice.html.

\section{Scholarly works}

Ally, Yaseen and Laher, Sumayya. "South African Muslim Faith Healers Perceptions of Mental Illness: Understanding, Aetiology and Treatment.” Journal of Religion and Health no. 47 (2008): 45-56.

Dein, Simon and Illaiee, Abdul Samad. "Jinn and mental health: looking at jinn possession in modern psychiatric practice." The Psychiatrist 37 (2013): 290-293. <http://www.rukjahandhealing.co.uk/articles/>.

Duranović, Elvir. "Narodna religija, narodni Islam u Bosni i Hercegovini - bosanski Islam i Islamska tradicija Bošnjaka - diferencirajući faktori," Glasnik IZ 11-12(n.d.): 1077-1094.

Đorđević, Tihomir. Naš narodni život. Beograd: Prosveta, 1984.

El-Zein, Amira. Islam, Arabs and the Intelligent World of the Jinn. Syracuse: Syracuse University Press, 2009.

Garčević, Muhamed. Zapisi i hamajlije. Sarajevo: Hrvatska narodna tiskara (podružnica), 1942Garčević, Muhamed. Zapisi i hamajlije. Sarajevo: Hrvatska narodna tiskara (podružnica), 1942.

GeertzGeertz, Clifford. The iterpretation of cultures. New York: Basic Books, 1973., Clifford. The iterpretation of cultures. New York: Basic Books, 1973.

Hanely, Jane and Brown, Amy. "Cultural Variations in Interpretation of Postnatal Illness: Jinn Possession Amongst Muslim Communities" Community Mental Health Journal 50(2014): 348.

Hangi, Antun. Život i običaji Muslimana. Sarajevo: Svjetlost, 1990.

Islam, F. and Campbell, R. A. ““'Satan Has Afflicted Me!” Jinn-Possession and Mental Illness in the Qur'an” Journal of Religion and Health 53(2014): 229-243.

Khalifa, Najat and Hardie, Tim. "Possession and jinn" JRSM, 98 (August 2005): 351-353.

Lugo, Louis. The World's Muslims: Unity and Diversity. Washington: Pew Forum, 2012. http://assets.pewresearch.org/wp-content/uploads/sites/11/2012/08/the-worlds-Muslims-full-report.pdf.

Norris, Harry Thirlwall. Islam in the Balkans. London: Hurst\&Co, 1993.

Pauly, Robert J. Jr. Islam in Europe. Integration or marginalization? Aldershot, Hants: Ashgate, 2004.

Saldaňa, Johnny. The coding manual for qualitative researchers. Los Angeles: SAGE, 2009.

Sengers, Gerda. Women and Demons: Cult Healing in Islamic Egypt. Leiden: Brill, 2003.

Serdarević, Mevlida and Omanić, Ajnija. Bošnjačka kultura ponašanja. Sarajevo: Art 7, 2009.

Smajić, Aid. "Bosnia and Herzegovina (Country report).” Yearbook of Muslims in Europe. Edited by Joergen S. Nielsen et al. (Leiden: Brill 2011), vol. 3, p. 110.

Suhr, Christian. "The failed image and the possessed: examplesSerdarević, Mevlida and Omanić, Ajnija. Bošnjačka kultura ponašanja. Sarajevo: Art 7, 2009 of invisibility in visual anthropology and Islam,” Journal of the Royal Anthropological Institute. 2015. http://onlinelibrary.wiley.com/doi/10.1111/1467-9655.12168/full. 
Štulanović, Muharem. Zapisi u BiH. Bihać: Islamski Pedagoški Fakultet, 2016.

Thomas, Wiliam Isaac and Thomas, Dorothy Swaine. The child in America: Behavior problems and programs. New York: Knopf, 1928.

Whitehouse, Harvey. "Modes of Religiosity and the Cognitive Science of Religion.” MTTR 16 (2004): 321-336.

Whittaker, Sara et al. "An Exploration of Psychological Well-being with Young Somali Refugee and Asylumseeker Women.” Clinical Child Psychology and Psychiatry, 10 (February 2005): 177-196.

Yoder, Don. “Toward a Definition of Folk Religion." Symposium on Folk Religion 33: 1(January 1974), 2-15. 